\title{
Conceptualisation as Key Factor in Seizing Design Project in Studio Learning Environment
}

\author{
Fatimah Mohamad Adi ${ }^{1}$ Khairul Anwar Mohamed Khaidzir², Ismail Said² \\ 1 School of Postgraduate Studies \\ ${ }^{2}$ Faculty of Built Environment \\ Universiti Teknologi Malaysia, Skudai, 81310 Johor Bahru, Malaysia \\ ummitariq@gmail.com
}

\begin{abstract}
This study provides insight into the role of experience in facilitating conceptualisation process to enable students to harness relevant problems-solving skills. One of the key strategies of the current study is to analyse how students transform their ideas from abstract to physical form through the conceptualisation process within the studio learning environment. Two aspects were considered (1) the factors that influence the student's actions in designing, and (2) the role of critique in stimulating the student's conceptual design towards final design stage. Evidences were gathered from students' dynamic cognitive interactions with knowledge and experience as transpired through the studio environment.
\end{abstract}

Keywords: Conceptualisation, conceptual design process, reflective knowledge

eISSN 2398-4295 @ 2018 . The Authors. Published for AMER ABRA cE-Bs by e-International Publishing House, Ltd., UK. This is an open-access article under the CC BY-NC-ND license (http://creativecommons.org/licenses/bync-nd/4.0/). Peer-review under responsibility of AMER (Association of Malaysian Environment-Behaviour Researchers), ABRA (Association of Behavioural Researchers on Asians) and cE-Bs (Centre for EnvironmentBehaviour Studies), Faculty of Architecture, Planning \& Surveying, Universiti Teknologi MARA, Malaysia.

DOI: http://dx.doi.org/10.21834/ajbes.v3i12.121 


\subsection{Introduction}

The design studio environment becomes an important formative platform for critical reflections on urban issues to be incorporated into design work (Batuman \& Altay, 2014). Its play a vital role in educating, training, and producing future architects and environmental designers who are mindful in addressing sustainable issues in the built environment. The nature of studio curriculum that incorporates real world simulations enables the students to make an effective connection between overarching theories and concepts, to relevant skills acquisition, and real-life application. Therefore, the understanding on how the students' works in such phenomena of design problem in the studio learning environment are crucial as it involves knowledge acquisition, creativity, critical and innovative thinking, pragmatic exercises, and conception theories (Ayob et al., 2011; Luqman \& Utaberta, 2011; Oxman, 1999). Such of dynamic knowledge integration in the learning system should prompt interest among educators and advocates of architectural design education, at least along the following general line of inquiry: how are urban issues incorporated into architectural design studios? The purpose of the study is to examine how the conceptualisation process of design within the studio learning environment has aid students in completing their studio task. Through this understanding, it offered vivid knowledge on the constraints and processes faces by the students, as well as ways students tackle those problems on how they work, draw, and think.

\subsection{Literature Review}

\section{Conceptualisation: Meaning and Vehicles of the Process}

Conceptualisation is described as a process that harnesses the student's problem solving skill through its iterating back-and-forth activities, generative and evaluative stages that gradually converge and filter the student's perspective on a preferred conceptual solution (The Design Society, 2012). Four elements that make up the conceptualisation process are prior knowledge, episodic memory that aids the recall of images previously perceived, case study precedence and recursive approaches, and strategies employed throughout the process (Lawson, 2004, 2006; Menezes \& Lawson, 2006). This understanding highlights that conceptualisation is a tacit knowledge that obtained through a direct engagement with the activities. Through a direct experience (Kolb, 1984) and careful consideration (Schon, 1983) on the events or activities, it could potentially transform abstract knowledge into reflective knowledge and essential in the development of new knowledge. Thus, the essence of this tacit knowledge in the studio learning environment is optimally acquired through independent efforts to learn and reflect in the form of abstract, communications, and representation of depictions (Goldschmidt, 1991; Hutchins, 2000; Reber, 1989; Uluoglu, 2000).

Previous studies revealed that the drawings and sketching activities has become mediums of conversation to the students (Schon, 1983). Through the sketching activities, it have evoked the students to the unexpected discoveries (Schon \& Wiggins, 1992), triggered new meanings (Goldschmidt, 1991), and illustrated the ability to transform and generate new images in mind while sketching (Kavakli \& Gero, 2001; Kavakli, Suwa, Gero, \& Purcell, 1999). 
Many studies have argued on student's difficulties in learning the design process (Gobert, 1999; Waldron \& Waldron, 1996; Zeitz, 1997). Some claimed students have weakness in the ability of sketching (Kavakli \& Gero, 2001), generated lower number of sketches and interpretations (Purcell \& Gero, 1998), and have limited access to knowledge that resulted in failure to recognise problems and reflect on the previous projects (Ahmed et al., 2003; Lawson, 2004). However, (Higgins et al., 2009) believed that the most important value of studio learning is locates at its Socratic method of open inquiry and active learning. Furthermore, Graham (2003) and Utaberta et al. (2011) added that by continuously been active in exploring sketches and engaging with interactive communication with the studio instructors, the students enable to seize the difficulties offered by the studio learning environment.

\subsection{Methodology}

The study highlights the outcome of an architectural studio project undertaken by respondents in transforming a vacant land into a community service centre. The respondents were architectural students from the third year Design Project course SBEA3158 of semester 1, session 2013/2014 at the Faculty of Built Environment, Universiti Teknologi Malaysia.

\section{Research Approaches, Data Collection and Analysis}

The study conducted on a limited sample of 10 students based on purposive sampling method. The first attempt employed on a questionnaire survey to identify trends of constraints within the studio learning environment. The study was further employed by a qualitative approach of a case study investigation on numerical relationships and patterns on student's activities and interviews. Ten students were randomly selected from two different backgrounds of diploma qualification and matriculation study within the third year cohort. Units of analysis derived for the study have facilitated the description of critical phases of the design process experienced by the observed architectural students. More crucially, such knowledge further infers to relatively rich conceptualisation activities and processes taking place among the students observed.

Data was collected through semi-structured interviews, observations and analysis on the student's sketches. The data was assessed from two critical design stages; (1) idea development stage and (2) refinement stage. Findings from the comparison of student's activities in those stages help to demarcate the nature of design conceptualisation process as observed through studio learning. The study also applied a content analysis of the selected students' sketches that facilitated the categorisation of such works into specific types of activities, forms, and patterns. Results from these analyses provided critical descriptions and relationships in measuring students' abilities in designing. Through these identification and examination of student's activities, forms, and patterns, the study has generated an in-depth understanding about conceptualisation and knowledge integration. This further helped to explain the role of conceptualisation in dealing with the urban issues found within the studio learning environment. The end results suggest that students who 
actively explored, iterated, and undertook critiques generate more productive design depictions.

\subsection{Results and Discussions}

\section{Trends of Constraints that Influence Student's Actions}

Table 1 showed the results on the questionnaires of the ten students. Seven students agreed that the conceptual design development stage is the most dominant session that contributes higher constraints and difficulties. It is followed by the critique sessions and the final assessment session. Through interviews, the students affirmed that the conceptual design development stage mostly involved with heavy commitment in term of design workloads, repeating self-explored, and series of communication with the studio instructors. This nature of design process that enforced them to construct ideas, display works to the instructors, and reiterate ideas based on the commented feedbacks caused for uncomforted and unsecured feelings among students. In contrast, the other three sessions of design briefing, site inventory, and reviewing documents engaged for more leisure mode for the students. The students enjoyed these three design sessions due to less of complicated design activities and only focusing on problem identification of the proposed site.

From the interviews and observation on student's sketches, the students facing difficulties at four phases of designing centred primarily within the idea development stage and during the refinement design stage. These four phases are conceptualising an initial conceptual plan, adapting the case studies into the plan, returning activities to the previous concept, and changing the concept (refer Table 2). Compared to the previous studies, scholars affirmed that the design processes have generated several cognitive activities that varied in action (Kavakli et al., 1999; Purcell \& Gero, 1998). It is verified with the current study which has revealed that the students started to feel the stress pertaining to cognitive activities at the moment conceptual design development stage begins in earnest. When asked about the possible factors contributing toward such a condition, the majority of observed students reflected upon four critical factors; lack of knowledge and design experience, complexity of design stages, confusion on the design requirements, and conflict with the lecturers. The trend on constraints exists among the students in their design process is illustrated in Table 1.

Table 1: Factors on difficulties in designing (from student's perspectives)

Elements that exists in conceptualisation of design process

\begin{tabular}{l|l|c|c}
\hline Items questioned in the survey & Option of answers & \multicolumn{2}{|c}{$\begin{array}{c}\text { Frequency on } \\
\text { student }\end{array}$} \\
\cline { 3 - 4 } & & 1 & 2 \\
\hline \multirow{2}{*}{$\begin{array}{l}\text { 1. Which studio sessions make you stress the } \\
\text { most? }\end{array}$} & Design briefing & 3 & 7 \\
\cline { 2 - 4 } & Site inventory & 3 & 7 \\
\cline { 2 - 4 } & Review plans, reports, and case study & 3 & 7 \\
\cline { 2 - 4 } & Conceptual design development & 7 & 3 \\
\cline { 2 - 4 } & Critiques session with studio instructors & 5 & 5 \\
\cline { 2 - 4 } & Final presentation & 5 & 5 \\
\hline
\end{tabular}


2. What are the factors that contribute to the difficulties in design process?

\begin{tabular}{|l|l|l|}
\hline Lack of knowledge and experience & 6 & 4 \\
\hline Complexity on the nature of design stage & 5 & 5 \\
\hline Confusion on the themes and client's needs & 4 & 6 \\
\hline Conflict with the studio instructors & 3 & 7 \\
\hline
\end{tabular}

Note:

1: Indication on number of students 'AGREED' with the answer

2: Indication on number of students perceived as the answer are 'NOT RELATED'

(Source: Architectural Student's Survey, Semester 1, Session 2013/2014)

Table 2 illustrates the four constraints and twelve sub-constraints pertaining studio design process reported by the students. The finding shows that during the initial stage of idea development, students struggled with the issue of constructing their design idea. The students felt unsecured whenever their friends have constructed the idea first while they have none. Some of the students worried on their initial idea been rejected and need to be refined again, while other students confused on how to adopt and transfer the reliable elements that they found from the case studies into their design idea. These findings indicate that the students have problem in knowledge transmission of their critical thinking and problem solving from the site into the design stage.

During the refinement design stage, these worries move towards adaptation of elements into the design idea, iteration and incremental of ideas commented by the studio instructors, justification and maintenance of constructed idea. The finding showed that students have problems dealing with the nature of design process on time constraints and critiques session, self-satisfaction in decision making, the instructor's teaching approach, and self-acceptance on the given feedbacks. Such problems point to the students' difficulty in undertaking design reasoning as part of the iterative and incremental nature of the design process, especially in the construction and reconstruction of design ideas and concepts.

Table 2: Types of constraints in the design process of studio learning reported by students

\begin{tabular}{|c|c|c|c|c|}
\hline Stage & $\begin{array}{l}\text { Worries and } \\
\text { constraints face by } \\
\text { students }\end{array}$ & Sub-constraints & $\begin{array}{l}\text { Category of } \\
\text { constraint }\end{array}$ & $\begin{array}{l}\text { Domain of } \\
\text { influence }\end{array}$ \\
\hline $\begin{array}{l}\text { Idea } \\
\text { development }\end{array}$ & $\begin{array}{l}\text { C1. Construction of the } \\
\text { main/initial idea }\end{array}$ & $\begin{array}{l}\text { 1. Availability of } \\
\text { idea in initial } \\
\text { stage }\end{array}$ & $\begin{array}{l}\text { Knowledge } \\
\text { transmission from } \\
\text { site to design }\end{array}$ & $\begin{array}{l}\text { Individual } \\
\text { differences } \\
\text { in abilities }\end{array}$ \\
\hline $\begin{array}{l}\text { (transaction } \\
\text { between two } \\
\text { stages) }\end{array}$ & $\begin{array}{l}\text { C2. Adaptation of the } \\
\text { case studies into design } \\
\text { idea }\end{array}$ & $\begin{array}{ll}\text { 2. } & \text { Confusion on } \\
\text { adapting } \\
\text { elements }\end{array}$ & $\begin{array}{l}\text { Critical thinking and } \\
\text { problem solving }\end{array}$ & \\
\hline $\begin{array}{l}\text { Refinement } \\
\text { design stage }\end{array}$ & $\begin{array}{l}\text { C3. Iteration and } \\
\text { incremental process of } \\
\text { main idea }\end{array}$ & $\begin{array}{ll}\text { 3. } & \text { Design have } \\
\text { timeframe and } \\
\text { limitation }\end{array}$ & $\begin{array}{l}\text { Nature of design } \\
\text { process }\end{array}$ & $\begin{array}{l}\text { Management } \\
\text { of self- } \\
\text { conduct and } \\
\text { acceptance }\end{array}$ \\
\hline
\end{tabular}


Mohamad Adi, F., et.al.. / Asian Journal of Behavioural Studies (AjBeS), 3(12) Jul / Aug 2018 (p.43-52)

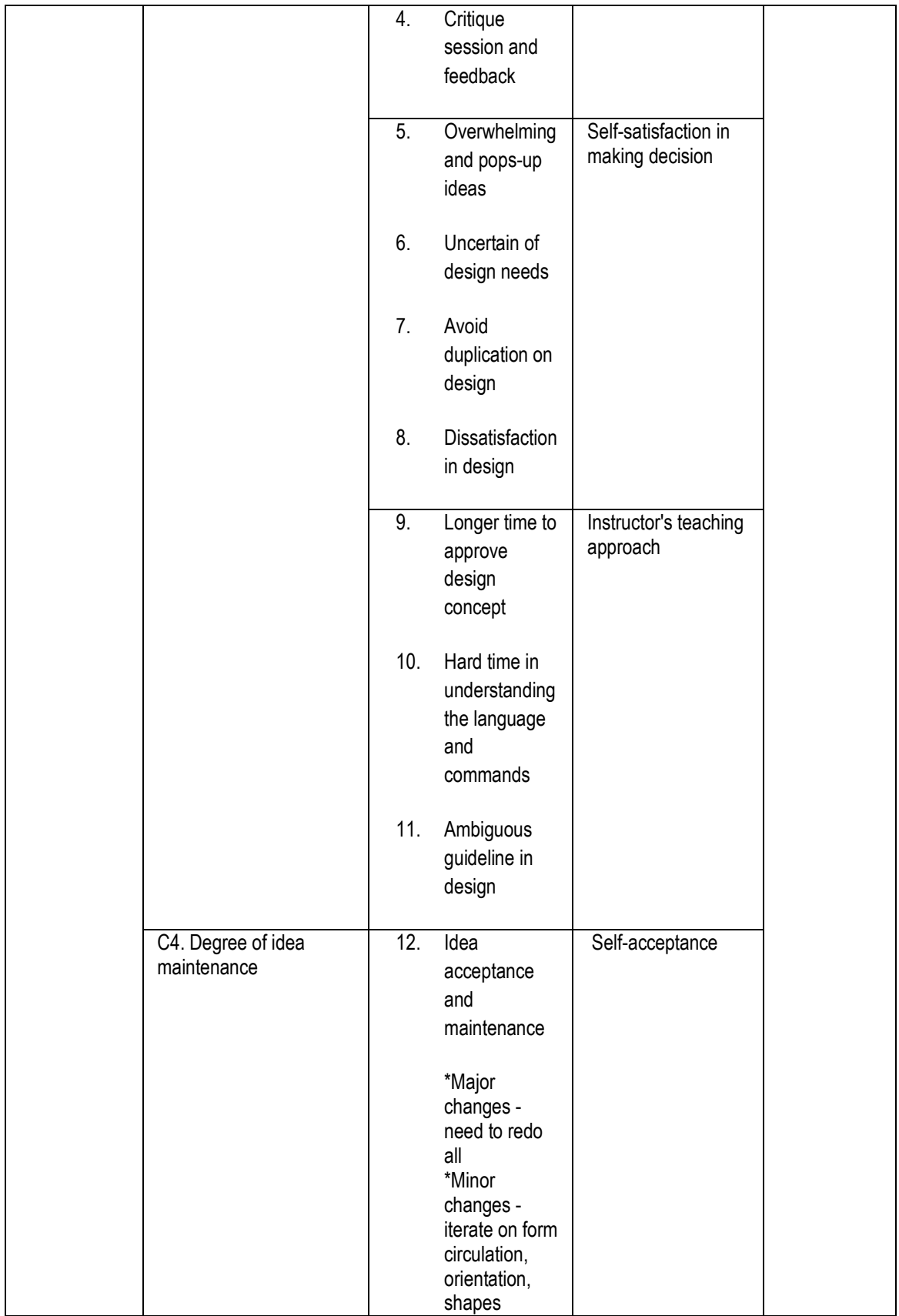




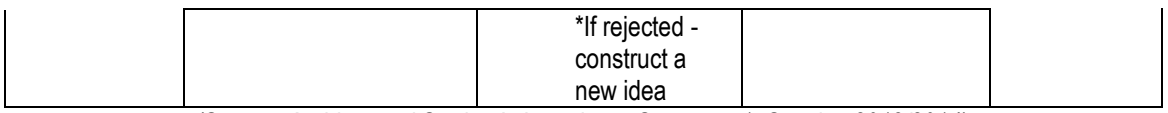

(Source: Architectural Student's Interviews, Semester 1, Session 2013/2014)

\section{Conceptualisation process in student's sketches}

For better understanding on the nature of conceptualisation process as experienced by the architectural students, the following illustrations in Table 3 provides a description of the design process with reference to sketches generated by Tan, a mainstream student (represent by A), and Zahidah, a diploma student (represent by B).

During the initial stage of idea development, student $A$ had directly adopted the metaphorical element on the symbol of the autism awareness ribbon. The student used the symbol as the key design generator and manipulated the geometrical curve of ' $A$ ' from of the word 'autism' (refer sketches A-1). He then transposed the initial metaphorical images into a set of spatial arrangement by integrating the information and circulation of wind and sun orientation to evolve the initial design ideas. Later, it is observed that the student reiterated on 13 different images and design forms in the same page. The student reiterated the form from $r 1$ to $r 9$ to improve the landscape area that represent in a yellow circular shape. After the 10th of reiterated images, the student took out the initial circular images and replaced with a series of pillars to denote the placement of shading device along the entrance and drop-off area.

As for student $B$, she observed the routine activities performed by the children during the site inspection at the children spastic centre. During the indoor play time, the children were utilised their limited spaces with passive activities such as reading, taking nap, walking around the square walls, circulating the instructor to hear stories, and interacting with one another. However, during the outdoor play time, the children were observed to have active activities with friends such as running, cycling, marking tower and putting cards at the garden fences, twirling and swinging around the garden, and exploring the natural elements of trees, insects, sands, and water drop (refer sketches B-1). This student drew all the observed activities in the form of denoting user's characteristics. During the refinement design stage, it is observed that student $B$ still struggled in exploring the explicit design form (refer sketches B-2). The forms elicited by this student are not fully formable as compared to the sketches exhibited by student $A$.

This finding suggests that both students $A$ and $B$ have successfully transformed the descriptive information from the site inspection into spatial design forms. The only difference is on student's approaches and speed in perceiving the information which student A tended to adopt the geometrical element, while student B tended to absorb the characteristics exhibited by the users. The results also suggest that during the refinement design stage, it involved active iteration and exploration on the explicit design forms. This is support by data exhibit in Table 3 whereas lots of unstructured entities and unintended features were identified in the page of student's sketches. 
Table 3: Examples of sketches explicated by the mainstream and diploma student during their design process of studio learning

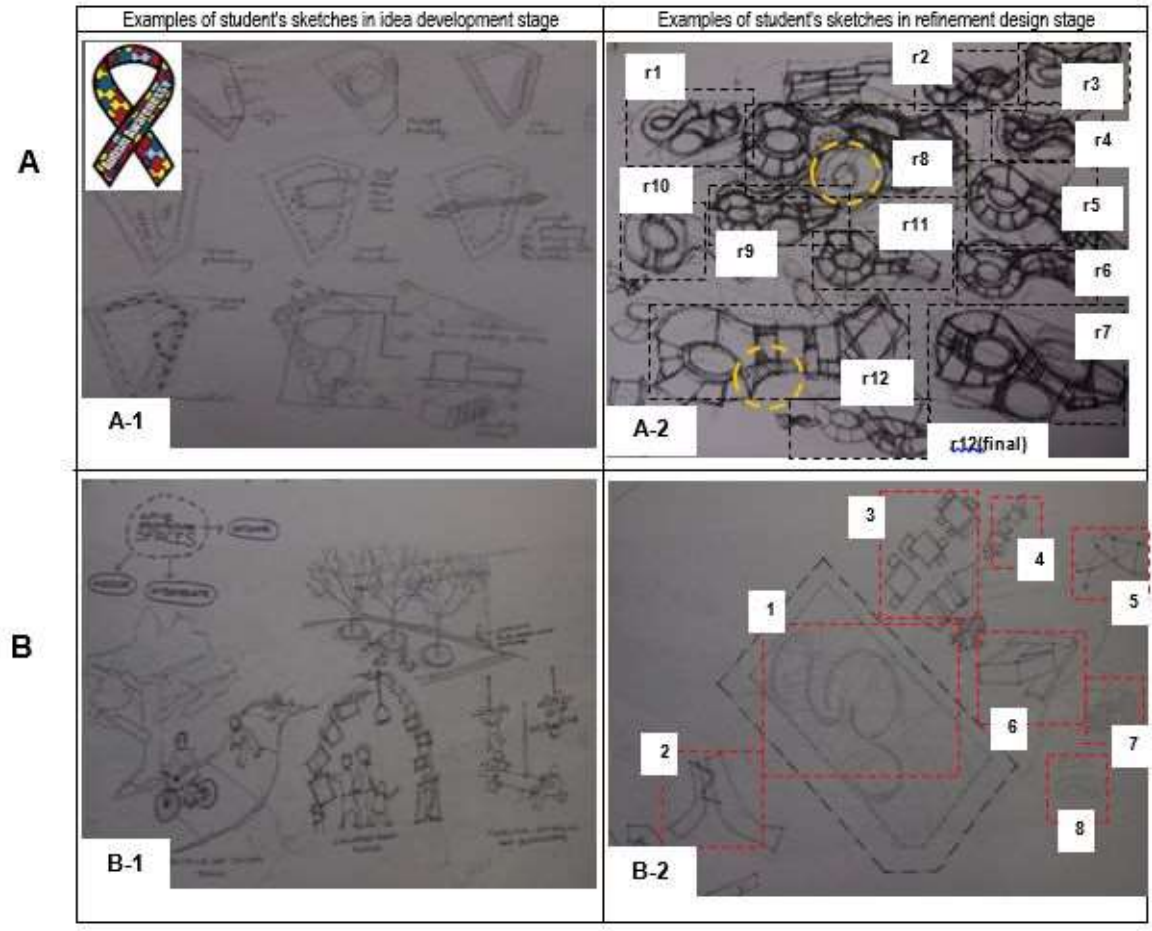

(Source: Architectural Student's Sketches, Semester 1, Session 2013/2014)

\section{Role of studio critiques in assisting students towards the end process}

For all the effort, Tan had achieved B+ in the final assessment of the related design project. Based on a following interview, Tan admitted to miss a number of critique and tutorial sessions with the studio instructor. The student also claimed that he loved to work alone and preferred to explore the feasibility of spaces within the context of his conceptual design in a solitary manner. This was testified by the studio instructor who had revealed that the student was very expressive in developing interesting design forms, however appeared to have 'frozen' his conceptual design very early in the design phase and subsequently began to isolate himself from meeting the studio master by missing out on critique sessions. The student eventually managed to develop the proposed design from concept stage to final outcome in the process, had responded accordingly to the design requirements as stipulated in the given task. In contrast, Zahidah achieved B grade for the final assessment. According to her studio instructor, the student loses focus in developing her design concept and tended to circulate on same design patterns even though the student have a frequent critique sessions and good technical ability. 


\subsection{Conclusion}

In conclusion, the conceptualisation process within the studio learning environment plays a major role in knowledge integration from the abstract into the physical form. This knowledge integration correlates with the domain of the stored knowledge in the student's mind, while reflective knowledge results in the transformation of the initial conceptual idea into series of reinterpreted images. The next level that aids the activation of student's activities is based on frequent feedbacks from the studio instructors which transform the reflective knowledge into a new form of generic knowledge. In the current study, students construct different pattern of conceptualisation process under the influenced of four factor; (i) student's prior knowledge, (ii) access to knowledge in the form of critique, synthesis knowledge, and selfexploration, (iii) the ways students perceived difficulties and complexity of the design task, and (iv) the internal factors in the individual differences that vary in term of learning style and preference, design abilities, and the communication skill.

\section{Acknowledgement}

This study is funded by Universiti Teknologi Malaysia, Skudai and the Ministry of Higher Education (MOHE) of Malaysia under a Research University Grant (RUG) entitled 'The Development of the Conceptualisation Process in Design Activities: A Case Study on Studio Learning Abilities and Performance at Universiti Teknologi Malaysia' (Q.J130000.2521.07H79).

\section{References}

Ahmed, S., Wallace, K. M., \& Blessing, T. M. (2003). Understanding the Differences Between How Novice and Experienced Designers Approach Design Tasks. Research Engineering Design, 14, 1-11. doi:10.1007/s00163-0020023-z

Ayob, A., Hussain, A., Mustafa, M. M., Fauzi, M., \& Shazi, A. (2011). Nurturing Creativity and Innovative Thinking through Experiential Learning. Procedia Social and Behavioral Sciences, 18, 247-254. doi:10.1016/j.sbspro.2011.05.035

Batuman, B., \& Altay, B. D. (2014). Critique by design: Tackling urban renewal in the design studio. Urban Design International, (January), 1-21. doi:10.1057/udi.2013.40.

Gobert, J. D. (1999). Expertise in the Comprehension of Architectural Plans: Contribution of Representation and Domain Knowledge. Visual and Spatial Reasoning in Design.

Goldschmidt, G. (1991). The Dialectics of Sketching. Creativity Research Journal, 4(2), 123-143.

Graham, E. . (2003). Studio Design Critique: Student and Faculty Expectations and Reality. Louisiana State University and Agricultural and Mechanical College. Retrieved from http://www.etd.isu.edu/dos/available/etd0611103-184324.

Higgins, M., Aitken-Rose, E., \& Dixon, J. (2009). The Pedagogy of the Planning Studio : A View from Down Under. Journal for Education in the Built Environment (JEBE), 4(1), 8-30. 
Hutchins, E. (2000). Distributed Cognition. International Encyclopedia of the Social \& Behavioral Sciences (IESBS), 2068-2072.

Kavakli, M., \& Gero, J. S. (2001). Strategic Knowledge Differences Between an Expert and a Novice Designer (pp. 1-10). Sydney.

Kavakli, M., Suwa, M., Gero, J., \& Purcell, T. (1999). Sketching Interpretation in Novice and Expert Designers. In B. Gero, J.S. Tversky (Ed.), Visual and Spatial Reasoning in Design (pp. 209-220). Cambridge: Key Centre of Design Computing and Cognition, University of Sydney.

Kolb, D. . (1984). Experiential learning : experience as the source of learning and development. In E. Cliffs (Ed.), Learning from Experience (2006th ed., pp. 19-38). New Jersey: Prentice-Hall. Retrieved from http://www.learningfromexperience.com/images/uploads/process-of-experiential-learning.pdf

Lawson, B. (2004). Schemata, gambits and precedent: some factors in design expertise. Design Studies, 25, 443457. doi:10.1016/j.destud.2004.05.001

Lawson, B. (2006). How Designers Think: The Design Process Demystified (4th Editio.). United Kingdom: Architectural Press.

Luqman, N. N. I., \& Utaberta, N. (2011). Pembelajaran Dalam Studio Rekabentuk Senibina. Kongres Pengajaran dan Pembelajaran UKM, 1-9.

Menezes, A., \& Lawson, B. (2006). How Designers Perceive Sketches. Design Studies, 27, 571-585. doi:10.1016/j.destud.2006.02.001

Oxman, R. (1999). Chapter 12 The Mind in Design : A Conceptual Framework for Cognition in Design Education. In R. Oxman (Ed.), Design Knowing and Learning Cognition in Design Education (pp. 269-295). Haifa.

Purcell, T., \& Gero, J. S. (1998). Drawings and the Design Process. Design Studies, 19, 389-430.

Reber, A. S. (1989). Implicit Learning and Tacit Knowledge. Journal of Experimental Psychology, 118(3), 219-235.

Schon, D. A. (1983). The Reflective Practitioner. How Professionals Think in Action (1995th ed.). New York: Basic Books.

Schon, D. A., \& Wiggins, G. (1992). Kinds of Seeing and Their Functions in Designing. Design Studies, 13(2), 135156.

The Design Society. (2012). Design Thinking for Educators: Toolkits. The Design Society. Retrieved December 20, 2012, from http://www.designthinkingforeducators.com/ p.11.

Uluoglu, B. (2000). Design Knowledge Communicated in Studio Critiques. Design Studies, 21, 33-58.

Utaberta, N., Hassanpour, B., Ani, A. I. C., \& Surat, M. (2011). Reconstructing the Idea of Critique Session in Architecture Studio. Procedia Social and Behavioral Sciences, 18, 94-102. doi:10.1016/j.sbspro.2011.05.014

Waldron, M. B., \& Waldron, K. J. (1996). The Influence of the Designer's Expertise on the Design Process. Mechanical Design: Theory and Methodology. (pp. 5-20). Berlin Heidelberg: Springer.

Zeitz, C. M. (1997). Some Concrete Advantages of Abstraction: How Experts' Representations Facilitate Reasoning. Expertise in context (pp. 43-65). Menlo Park, California. 